\title{
ERRATUM
}

\section{Loneliness and the exchange of social support among older adults in Spain and the Netherlands - ERRATUM}

\section{MARTA M. SÁNCHEZ RODRIGUES, JENNY DE JONG GIERVELD and JOSE BUZ}

doi: 10.1017/So144686X12000839, published online by Cambridge University Press 21 September 2012.

The name of the first author was listed incorrectly in this paper.

The correct author name is:

\section{MARTA M. SÁNCHEZ RODRIGUEZ}

We apologise to Dr Sánchez Rodriguez and to the readers for this error. The original article has been updated to show the correct author name.

\section{REFERENCES}

Sánchez Rodrigues, M. M., De Jong Gierveld, J. and Buz, J. Loneliness and the exchange of social support among older adults in Spain and the Netherlands. Ageing $\mathcal{E}$ Society, published by Cambridge University Press, 21 September 2012. doi: $10.1017 /$ Sol 44686X12000839. 